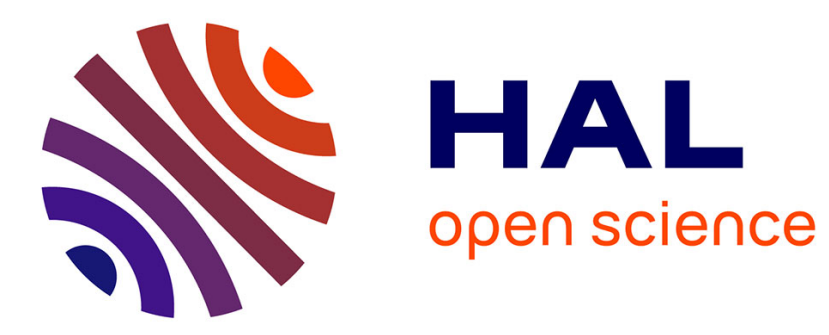

\title{
Cyclooctadiene Rh(I) Bis- and Tris(pyrazolyl)aluminate Complexes and Their Catalytic Activity on the Polymerization of Phenylacetylene
}

Omar J Garcia, Laure Vendier, Michel Etienne, Steven Gwaltney, Abigail Ressler, Miguel-Ángel Muñoz-Hernández

\section{To cite this version:}

Omar J Garcia, Laure Vendier, Michel Etienne, Steven Gwaltney, Abigail Ressler, et al.. Cyclooctadiene Rh(I) Bis- and Tris(pyrazolyl)aluminate Complexes and Their Catalytic Activity on the Polymerization of Phenylacetylene. Inorganic Chemistry, 2021, 60 (14), pp.10757-10763. 10.1021/acs.inorgchem.1c01434 . hal-03292668

\section{HAL Id: hal-03292668 https://hal.science/hal-03292668}

Submitted on 20 Jul 2021

HAL is a multi-disciplinary open access archive for the deposit and dissemination of scientific research documents, whether they are published or not. The documents may come from teaching and research institutions in France or abroad, or from public or private research centers.
L'archive ouverte pluridisciplinaire HAL, est destinée au dépôt et à la diffusion de documents scientifiques de niveau recherche, publiés ou non, émanant des établissements d'enseignement et de recherche français ou étrangers, des laboratoires publics ou privés. 


\title{
Cyclooctadiene $R h(I)$ bis and tris(pyrazolyl)aluminate
}

\section{complexes and their catalytic activity on the polymerization}

\section{of phenylacetylene}

Omar J. Garcia ${ }^{1}$, Laure Vendier ${ }^{2}$, Michel Etienne, ${ }^{2}$ Steven Gwaltney ${ }^{1}$, Abigail Ressler ${ }^{1}$, and Miguel-Ángel Muñoz-Hernández ${ }^{1 *}$

${ }^{1}$ Department of Chemistry, Mississippi State University, Box 9573, Mississippi State, Mississippi 39762, USA, mmunoz@ chemistry.msstate.edu, https://www.munoz.chemistry.msstate.edu|

${ }^{2}$ LCC-CNRS, Université de Toulouse, CNRS, UPS, 205 route de Narbonne, 31077 Toulouse Cedex 4, France.

*Correspondence: mmunoz@ chemistry.msstate.edu

\begin{abstract}
In this work we report the transfer of alkyl bis and tris(pyrazolyl)aluminates metalloligands to an electron rich organotransition metal center. The 16-electron heterobimetallic complexes of rhodium $\left[\mathrm{Rh}(\mathrm{COD})\left\{\mathrm{Al}\left(\mathrm{Ph}_{2} \mathrm{pz}\right)_{2} \mathrm{Me}_{2}\right\}\right](\mathbf{3})$ and $\left[\mathrm{Rh}(\mathrm{COD})\left\{\mathrm{Al}\left(\mathrm{Ph}_{2} \mathrm{pz}\right)_{3} \mathrm{Me}\right\}\right](4)$ were obtained by metathesis reaction of the sodium bis (1) and tris(pyrazolyl)aluminate (2) with $[\mathrm{RhCl}(\mathrm{COD})]_{2}$. For 3, ${ }^{1} \mathrm{H}$ and ${ }^{13} \mathrm{C} \mathrm{NMR}$ in solution along with DFT calculations are consistent with a $\kappa^{2}$-coordination mode of the bis(pyrazolyl)aluminate to a square-planar $\mathrm{Rh}(\mathrm{I})$ center. The $\mathrm{X}$-ray structure of $\mathbf{4}$ shows a similar $\kappa^{2}$-coordination mode of the tris(pyrazolyl)aluminate to $\mathrm{Rh}(\mathrm{I})$ with a pendant pyrazolyl moiety. The attempted synthesis of aluminate-rhodium complexes with $\mathrm{R}=\mathrm{CF}_{3},{ }^{\mathrm{t}} \mathrm{Bu}$ on the pyrazolate ring afforded $\left[\mathrm{Rh}\left(\mathrm{R}_{2} \mathrm{pz}\right)(\mathrm{COD})\right]_{2}$ and $\left[\mathrm{R}_{2} \mathrm{pzAlMe}\right]_{2}$. Complexes 3 and 4 were investigated as homogenous catalysts in the polymerization of phenylacetylene
\end{abstract}


(PA). Both complexes showed enhanced catalytic activity compared to analogous rhodium poly(pyrazolyl)borates. Optimized gas phase DFT geometries of $\mathbf{3}, \mathbf{4}$, $\left[\mathrm{Rh}(\mathrm{COD})\left\{\mathrm{B}\left(\mathrm{Ph}_{2} \mathrm{pz}\right)_{2} \mathrm{Me}_{2}\right\}\right]$, and $\left[\mathrm{Rh}(\mathrm{COD})\left\{\mathrm{B}\left(\mathrm{Ph}_{2} \mathrm{pz}\right)_{3} \mathrm{Me}\right\}\right]$ were used to compare bite angles, while DFT geometries of 3-CO, 4-CO, $\quad\left[\mathrm{Rh}(\mathrm{CO})_{2}\left\{\mathrm{~B}\left(\mathrm{Ph}_{2} \mathrm{pz}\right)_{2} \mathrm{Me}_{2}\right\}\right], \quad$ and $\left[\mathrm{Rh}(\mathrm{CO})_{2}\left\{\mathrm{~B}\left(\mathrm{Ph}_{2} \mathrm{pz}\right)_{3} \mathrm{Me}\right\}\right]$ were employed to probe the electronic situation of rhodium center through IR CO stretching modes. The wider bite angles and the less electron-rich rhodium center of the poly(pyrazolyl)aluminates compared with their borate analogs could be implicated in the better performance of the active catalytic species during polymerization of PA.

\section{Introduction}

In stark contrast to the ubiquitous poly(pyrazolyl)borates ${ }^{1-4}$ very few reports of the heavier aluminum analogs are known ${ }^{5-6}$. In addition to easy tuning of steric and electronic properties promoted by the rich pyrazole chemistry, the change from boron to aluminum would be highly valuable due to the availability of ligands with wider bites and redox activity. Although the first

report on such a ligand system dates to the seventies, ${ }^{7}$ it was not until a few years ago that one of us reported the first authenticated sodium poly(pyrazolyl)aluminate exhibiting $\mathrm{Al}-\mathrm{CH}_{3}$ bonds. ${ }^{8} \mathrm{~A}$ remarkable series of poly(pyrazolyl)aluminates with Al-H bonds were also reported, ${ }^{6,9}$ with the aim of transferring the aluminate to different metal halides. Significantly the successful transfer of the hydrotris(pyrazolyl)aluminate $\left[\mathrm{HAl}\left(\mathrm{Ph}_{2} \mathrm{pz}_{3}\right]^{-}\right.$to a $\mathrm{Zn}$ center was accompanied by the undesired hydride transfer from aluminum to zinc giving $\left[\left\{\mathrm{HAl}\left(\mathrm{Ph}_{2} \mathrm{pz}\right)_{3}\right\} \mathrm{ZnH}\right]$. Other metal halides gave bimetallic pyrazolates $\left[\mathrm{M}_{2} \mathrm{X}_{2}\left(\mathrm{Ph}_{2} \mathrm{pz}\right)_{2}(\mathrm{THF})_{3}\right]$ with $\mathrm{M}=\mathrm{Mg}, \mathrm{X}=\mathrm{Br} ; \mathrm{M}=\mathrm{Co} ; \mathrm{X}=\mathrm{Cl}$, whereas reactions with first row transition metal halides of $\mathrm{Mn}, \mathrm{Fe}, \mathrm{Ni}$, and $\mathrm{Cu}$ produced intractable powders. ${ }^{9}$ These results highlight the difficulties of this chemistry and underpin the need for a better understanding of the factors that might lead to well-defined poly(pyrazolyl)aluminate 
metalloligands and complexes as it has been shown for the related tris(pyridyl)aluminates. ${ }^{10-17} \mathrm{We}$ surmised that a better performance of the poly(pyrazolyl)aluminate ligand system towards its transfer to a transition metal center could be achieved using alkyl groups on the aluminum atom instead of hydrogen to prevent hydride transfer on the one hand and, on the other hand, by using a more electron rich low-valent organotransition metal center, potentially leading to more stable, less reactive complexes. Indeed, we report herein the preparation and full characterization of the new bis and tris(pyrazolyl)aluminates $\quad\left[\left\{\mathrm{Na}(\mathrm{THF})_{2}\right\}\left\{\mathrm{Al}\left(\mathrm{Ph}_{2} \mathrm{pz}_{2} \mathrm{Me}_{2}\right\}\right] \quad\right.$ (1) and $\left[\{\mathrm{Na}(\mathrm{THF})\}\left\{\mathrm{Al}\left(\mathrm{Ph}_{2} \mathrm{pz}\right)_{3} \mathrm{Me}\right\}\right](\mathbf{2})$ and the complexation of aluminates $\mathbf{1}$ and $\mathbf{2}$ to an electron rich $\mathrm{Rh}(\mathrm{I})$ center to afford $\left[\mathrm{Rh}(\mathrm{COD})\left\{\mathrm{Al}\left(\mathrm{Ph}_{2} \mathrm{pz}\right)_{2} \mathrm{Me}_{2}\right\}\right](3)$ and $\left[\mathrm{Rh}(\mathrm{COD})\left\{\mathrm{Al}\left(\mathrm{Ph}_{2} \mathrm{pz}\right)_{3} \mathrm{Me}\right\}\right]$ (4). This chemistry is summarized in Scheme 1. We also disclose our findings on the catalytic activity of $\mathbf{3}$ and 4 in the polymerization of phenylacetylene (PA) comparing catalytic activities with the borate counterparts. DFT modelling helps rationalizing structural and reactivity differences between boron- and aluminum-based ligands. 

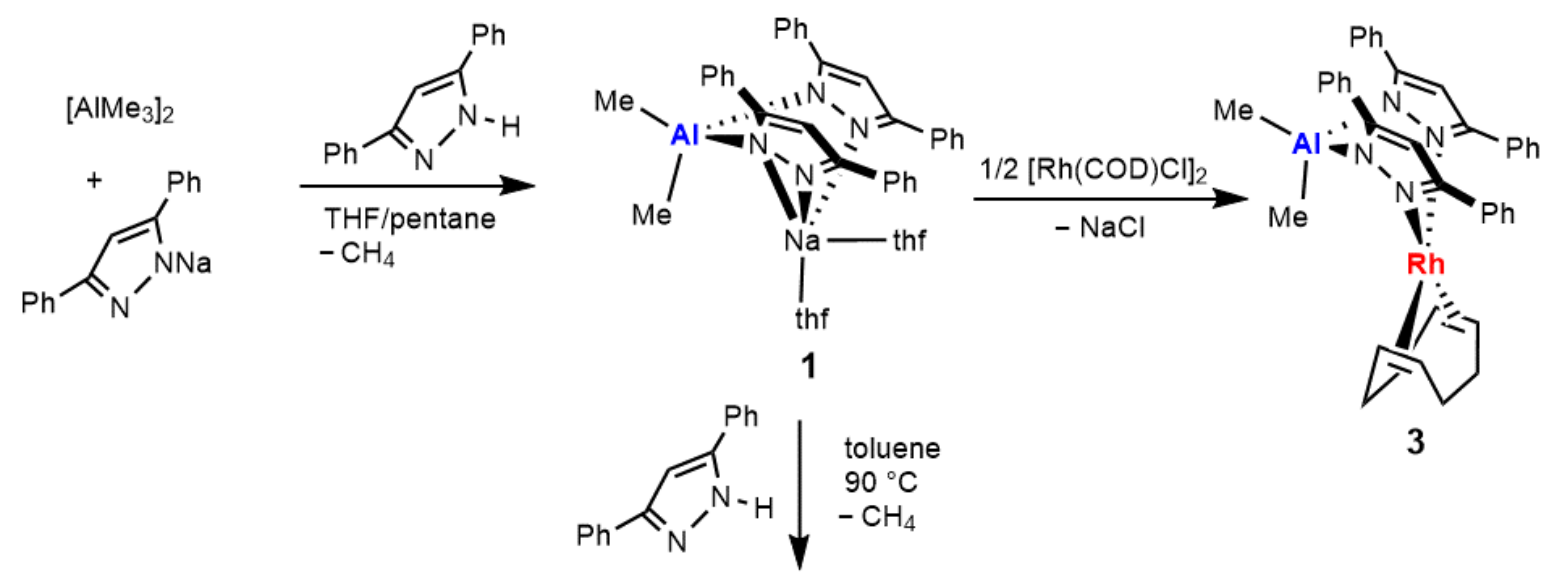

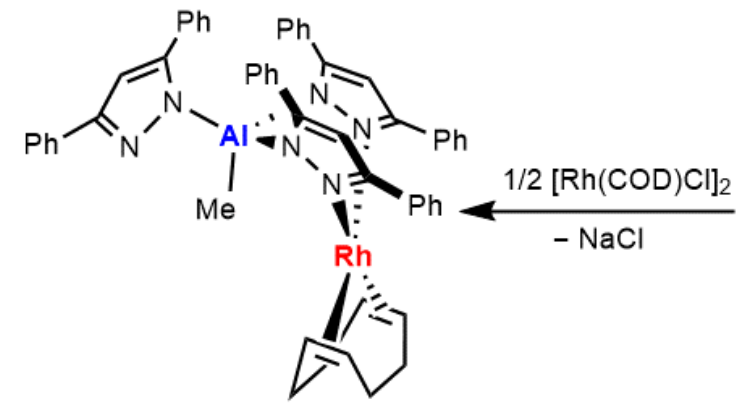

4

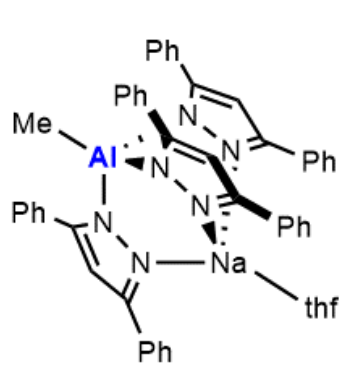

2

Scheme 1. New poly(pyrazolyl)aluminate chemistry.

\section{Results and discussion}

\subsection{Synthesis and characterization of bis(pyrazolyl)aluminate 1 and tris(pyrazolyl)aluminate}

2

1 and 2 were synthesized by nucleophilic addition of $\left[\mathrm{Na}\left(\mathrm{Ph}_{2} \mathrm{pz}\right)\right]$ to $\mathrm{AlMe}_{3}$ and the stepwise addition of 1 and 2 molar equivalents of $\mathrm{Ph}_{2} \mathrm{pzH}$ (Scheme 1). ${ }^{5,18-19}$ The bimetallic complex $\left[\mathrm{Ph}_{2} \mathrm{pzAlMe}\right]_{2}{ }^{20-21}\left({ }^{1} \mathrm{H}\right.$ NMR, benzene- $\left.d_{6}: \delta 7.42,7.03,6.26,-0.66\right)$ is a minor side product $(\sim 10 \%$ from ${ }^{1} \mathrm{H}$ NMR integration) of the reaction, albeit $\mathbf{1}$ was isolated analytically pure in $75 \%$ yield by crystallization in a 10:1 pentane-THF solution at ambient temperature. Complex 2 is readily obtained in $82 \%$ yield by reacting 1 with $\mathrm{Ph}_{2} \mathrm{pzH}$ at $90{ }^{\circ} \mathrm{C}$ in toluene. In contrast, ${ }^{18}$ the related aluminate $\left[\{\mathrm{Na}(\mathrm{THF})\}\left\{\mathrm{Al}\left({ }^{\mathrm{t}} \mathrm{Bu}_{2} \mathrm{pz}\right)_{3} \mathrm{Me}\right\}\right]$ is formed at ambient temperature, possibly reflecting 
that in the putative bridged $\mathrm{Al}-\mathrm{Me}-\mathrm{Na}$ intermediate $\left[\mathrm{Me}_{2} \mathrm{Al}\left(\mathrm{R}_{2} \mathrm{pz}\right)_{2} \mathrm{Na}\left(\mathrm{R}_{2} \mathrm{pzH}\right)\right]{ }^{18}$ the bridging methyl group is less nucleophilic when $\mathrm{R}=\mathrm{Ph}$. Consistently, in the ${ }^{1} \mathrm{H} \mathrm{NMR}$ spectra for $\mathbf{1}$ and $\mathbf{2}$ in benzene- $d_{6}$, the characteristic high field $\mathrm{CH}_{3}-\mathrm{Al}$ resonances appear at $\delta-0.35$ and -1.48 , respectively, at significantly higher field than those of $\left[\{\mathrm{Na}(\mathrm{THF})\}\left\{\mathrm{Al}\left({ }^{\mathrm{t}} \mathrm{Bu}_{2} \mathrm{pz}\right)_{2} \mathrm{Me}_{2}\right\}\right]_{2}$ and $\left[\{\mathrm{Na}(\mathrm{THF})\}\left\{\mathrm{Al}\left({ }^{\mathrm{t}} \mathrm{Bu}_{2} \mathrm{pz}\right)_{3} \mathrm{Me}\right\}\right]$ at $\delta 0.11$ and 0.58 , respectively. This shielding may be reinforced by the ring current effect of the 3,5-phenyl group(s) on the pyrazolyl ring(s). A similar situation is observed in the ${ }^{13} \mathrm{C}\left\{{ }^{1} \mathrm{H}\right\}$ NMR spectra where the methyl substituents show broad resonances at $\delta$ -6.28 and -8.98 , respectively $\left(\delta-1.2\right.$ and 1.8 for $\left[\{\mathrm{Na}(\mathrm{THF})\}\left\{\mathrm{Al}\left({ }^{\mathrm{t}} \mathrm{Bu} 2 \mathrm{pz}\right)_{2} \mathrm{Me}_{2}\right\}\right]_{2}$ and $\left[\{\mathrm{Na}(\mathrm{THF})\}\left\{\mathrm{Al}\left({ }^{\mathrm{t} B u_{2}} \mathrm{pz}\right)_{3} \mathrm{Me}\right\}\right], \quad$ respectively). Reflecting their remarkable kinetic and thermodynamic stability, solutions of the bis(pyrazolyl)aluminate $\mathbf{1}$ show no trace of the tris(pyrazolyl)aluminate $\mathbf{2}$, contrary to what is observed with the hydride version $\left[\left\{\mathrm{Li}(\mathrm{THF})_{2}\right\}\left\{\mathrm{Al}\left(\mathrm{Ph}_{2} \mathrm{pz}\right)_{2} \mathrm{H}_{2}\right\}\right]$ that exists in equilibrium with $\left[\{\mathrm{Li}(\mathrm{THF})\}\left\{\mathrm{Al}\left(\mathrm{Ph}_{2} \mathrm{pz}\right)_{3} \mathrm{H}\right\}\right] .{ }^{9}$

The X-ray crystallographic studies of complexes $\mathbf{1}$ and $\mathbf{2}$ reveal mononuclear complexes. In $\mathbf{1}$ the aluminate binds the sodium ion in a $\kappa^{3}-\mathrm{N}, \mathrm{N}, \mathrm{N}$ fashion that involves $\kappa^{1}$ coordination of one pyrazolyl ring $(\mathrm{Na}(1)-\mathrm{N}(1) 2.389(3) \AA)$ and $\kappa^{2}$ coordination of the second ring $[\mathrm{Na}(1)-\mathrm{N}(3)$ 2.374(3), $\mathrm{Na}(1)-\mathrm{N}(4) 2.747(3) \AA]$, see Figure 1. The sodium ion completes its pseudotetrahedral coordination sphere with two THF molecules. There is no indication of any "agostic" interaction between the $\mathrm{Al}-\mathrm{CH}_{3}$ group and $\mathrm{Na}(\mathrm{Na} \cdots \mathrm{C} 3.62 \AA)$ for which typical distances are in the range 2.569-2.873 $\AA .{ }^{8,18,22}$ The ${ }^{\mathrm{t}} \mathrm{Bu}$ analog of $\mathbf{1}$ also exhibits a $\kappa^{1}, \kappa^{2}$ coordination, but it appears as a dimer with Al-Me-Na bridges and a single THF ligand per Na. ${ }^{18}$ 


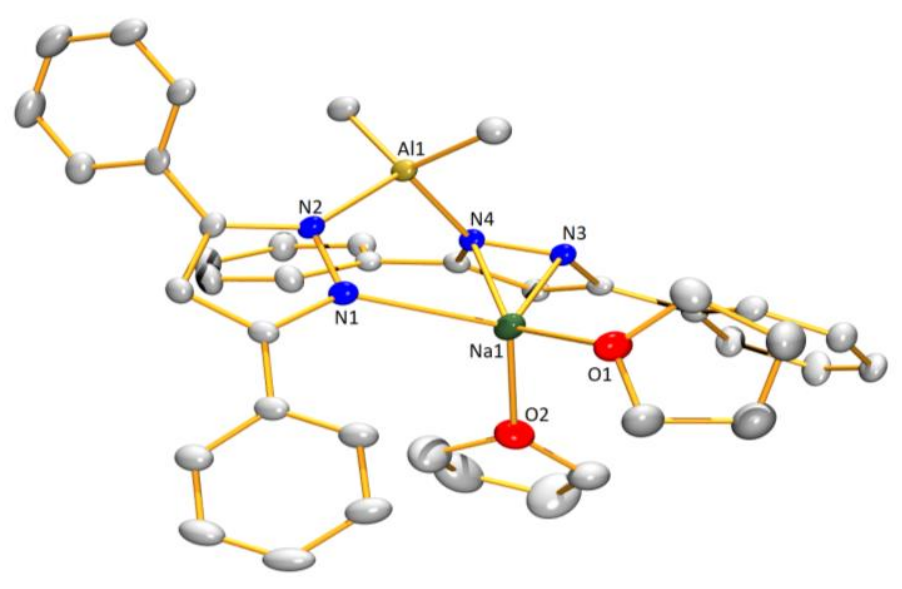

Figure 1. Perspective view of the X-ray structure of $\mathbf{1}$ showing thermal ellipsoids at the $30 \%$ probability level. Hydrogen atoms have been removed for clarity. Relevant bond lengths $(\AA)$ and angles (deg): $\mathrm{Na}(1)-\mathrm{O}(1) 2.277(3), \mathrm{Na}(1)-\mathrm{O}(2)$ 2.270(3), $\mathrm{Na}(1)-\mathrm{N}(1) 2.389(3), \mathrm{Na}(1)-\mathrm{N}(3)$ 2.374(3), $\mathrm{Na}(1)-\mathrm{N}(4) 2.747(3), \mathrm{Al}(1)-\mathrm{C}(31)$ 1.951(4), $\mathrm{Al}(1)-\mathrm{C}(32) 1.972(4) ; \mathrm{N}(1)-\mathrm{Na}(1)-\mathrm{N}(3)$ 105.95(10), N(1)-Na(1)-N(4) 77.11(8), O(1)-Na(1)-O(2) 101.56(10), C(31)-Al(1)-C(32) 119.96(16).

In 2 (Figure 2), the aluminate binds the sodium ion in a $\kappa^{3}-\mathrm{N}, \mathrm{N}, \mathrm{N}$ fashion that involves $\kappa^{1}$ coordination of the three pyrazolyl rings to the sodium ion $[\mathrm{Na}(1)-\mathrm{N}(2) 2.433(2), \mathrm{Na}(1)-\mathrm{N}(4)$ 2.377(2), $\mathrm{Na}(1)-\mathrm{N}(6) 2.386(2) \AA]$. The sodium ion completes its coordination sphere with one molecule of THF [Na(1)-O(1) $2.247(2) \AA]$. The sodium ion is only slightly out $(0.69 \AA)$ of the plane defined by the atoms $\mathrm{O}(1)-\mathrm{N}(4)-\mathrm{N}(6)$. The overall structure is highly distorted as judged by the $\mathrm{N}-\mathrm{Al}-\mathrm{N}$ angles and the torsion angles involving $\mathrm{Na}, \mathrm{Al}$, and the two $\mathrm{N}$ atoms of a given pyrazole ring. These atoms are far from being coplanar with a propeller shape being adopted around the $\mathrm{Al} \cdots \mathrm{Na}$ axis [torsion angles $\left(^{\circ}\right): \mathrm{Na}(1)-\mathrm{N}(2)-\mathrm{N}(1)-\mathrm{Al}(1) 38, \mathrm{Na}(1)-\mathrm{N}(4)-\mathrm{N}(3)-\mathrm{Al}(1)$ 49, $\mathrm{Na}(1)-$ $\mathrm{N}(6)-\mathrm{N}(5)-\mathrm{Al}(1) 52]$. In the ${ }^{\mathrm{t}} \mathrm{Bu}$ analog of 2 , a more distorted structure is observed with one pyrazolyl ring being $\kappa^{2}$ coordinated to $\mathrm{Na}$. 


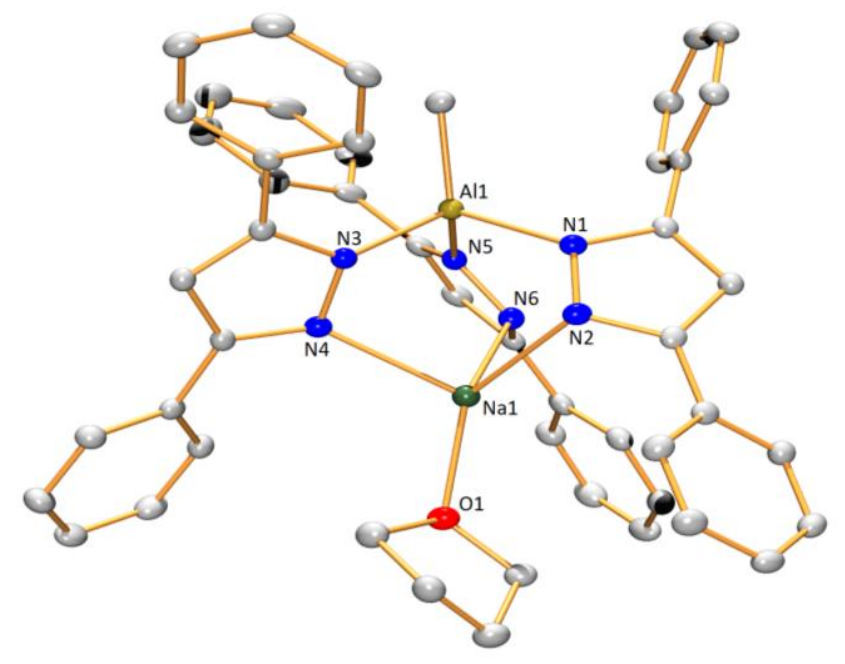

Figure 2. Perspective view of the X-ray structure of $\mathbf{2}$ showing thermal ellipsoids at the $30 \%$ probability level. Hydrogen atoms have been removed for clarity. Relevant bond lengths ( $\AA$ ) and angles (deg): $\mathrm{Na}(1)-\mathrm{N}(2)$ 2.433(2), $\mathrm{Na}(1)-\mathrm{N}(4)$ 2.377(2), $\mathrm{Na}(1)-\mathrm{N}(6) 2.386(2), \mathrm{Na}(1)-\mathrm{O}(1)$ 2.247(2), $\mathrm{Al}(1)-\mathrm{C}(50)$ 1.948(2); $\mathrm{O}(1)-\mathrm{Na}(1)-\mathrm{N}(2)$ 125.18(7), O(1)-Na(1)-N(4) 112.14(7), O(1)$\mathrm{Na}(1)-\mathrm{N}(6)$ 139.47(8), N(4)-Na(1)-N(6) 90.15(7), N(4)-Na(1)-N(2) 96.73(7), N(6)-Na(1)-N(2) 82.38(7), $\mathrm{N}(1)-\mathrm{Al}(1)-\mathrm{N}(3)$ 107.50(9), N(1)-Al(1)-N(5) 98.71(9), N(3)-Al(1)-N(5) 102.11(9).

2.2 Synthesis and characterization of bis(pyrazolyl)aluminate rhodium complex 3 and tris(pyrazolylaluminate) rhodium complex 4

We accomplished a metathesis reaction to transfer aluminates $\mathbf{1}$ and $\mathbf{2}$ to the rhodium center by treating 1 and 2 with $[\mathrm{Rh}(\mathrm{COD}) \mathrm{Cl}]_{2}$ in toluene at $100{ }^{\circ} \mathrm{C}$ overnight affording after workup the yellow 16-electron bimetallic complexes $\quad\left[\mathrm{Rh}(\mathrm{COD})\left\{\mathrm{Al}\left(\mathrm{Ph}_{2} \mathrm{pz}_{2}\right)_{2} \mathrm{Me}_{2}\right\}\right] \quad$ (3) and $\left[\mathrm{Rh}(\mathrm{COD})\left\{\mathrm{Al}\left(\mathrm{Ph}_{2} \mathrm{pz}\right)_{3} \mathrm{Me}\right\}\right](\mathbf{4})$ in 63 and $89 \%$ yield, respectively. Complexes 3 and 4 cocrystallize with $\left[\mathrm{Rh}\left(\mu-\mathrm{Ph}_{2} \mathrm{pz}\right)(\mathrm{COD})\right]_{2}$ in the solvents investigated, additionally; 4 also cocrystallizes with 2 . The best solvent for the extraction of $\mathbf{3}$ is toluene (93\% by ${ }^{1} \mathrm{H}$ NMR, Figure S19), while for 4 it is dichloromethane (DCM) (97\% by ${ }^{1} \mathrm{H}$ NMR, Figure S22). The room 
temperature ${ }^{1} \mathrm{H}$ and ${ }^{13} \mathrm{C}$ NMR spectra of $\mathbf{3}$ and $\mathbf{4}$ are consistent with both complexes proposed formulation. For 3, two distinct methyl signals for the $\mathrm{Al}-\mathrm{CH}_{3}$ moieties are observed in the ${ }^{1} \mathrm{H}$ and ${ }^{13} \mathrm{C}$ NMR spectra at $\delta 0.36,-2.15$; and $-4.26,-7.52$, respectively. These values are in reasonable agreement with the computed chemical shifts of the DCM solvated structure of 3 at $\delta 0.41,-2.22$; and $-3.18,-8.51$, respectively. The two most shielded resonances are attributed to the $\pi$ electronic currents of two flanking phenyl rings on a $\mathrm{CH}_{3}$ substituent on $\mathrm{Al}$ (Figure 3). The DFT calculated gas-phase structure seen in Figure 3 shows that the shortest carbon-hydrogen bond distances (1.10 $\AA$ ) in the $\mathrm{Al}-\mathrm{CH}_{3}$ moieties are those pointing towards phenyl centroids. The ${ }^{1} \mathrm{H}$ and ${ }^{13} \mathrm{C}$ NMR of 4 show two distinct methyne resonances assigned to two pyrazolate moities coordinated to the $\mathrm{Rh}$ center $\left({ }^{1} \mathrm{H},{ }^{13} \mathrm{C}\right.$ NMR: $\delta 6.39,107$, respectively), and one unbound pyrazolate $\left({ }^{1} \mathrm{H},{ }^{13} \mathrm{C}\right.$ NMR: $\delta$ $5.70,86.19$, respectively). Interestingly the borate analog of $4, \mathrm{Tp}{ }^{\mathrm{Ph}, \mathrm{Ph}} \mathrm{Rh}(\mathrm{COD})$ shows an average spectrum consisting of either $\mathrm{B} \leftrightarrow \mathrm{C}$ conformers in solution or fast interconverting $\mathrm{A} \leftrightarrow \mathrm{B} \leftrightarrow \mathrm{C}$ as shown in Scheme 2. ${ }^{23-26}$ Consistent with the NMR data, the X-ray structure of 4 (Figure 4) shows a $\kappa^{2}$-coordination mode of the tris(pyrazolyl)aluminate to a square-planar $\mathrm{Rh}(\mathrm{I})$ center. The unbound pyrazolyl substituent adopts an equatorial position resembling that of A-type isomer observed in $\left[\mathrm{Tp}^{\mathrm{Ph}} \mathrm{Rh}(\mathrm{COD})\right]^{25},\left[\mathrm{Tp}^{\mathrm{Ph}, \mathrm{Me}} \mathrm{Rh}(\mathrm{COD})\right]^{23}$ and in the open-diene complexes $\left[\mathrm{Tp}^{\text {tol }} \mathrm{Rh}\left(\mathrm{CH}_{2}=\mathrm{CH}_{2}\right)_{2}\right]$ and $\left[\mathrm{Tp}^{\text {tol }} \mathrm{Rh}\left(\mathrm{CH}_{2}=\mathrm{C}(\mathrm{Me}) \mathrm{C}(\mathrm{Me})=\mathrm{CH}_{2}\right)\right]^{27}$ (Scheme 2). The $\mathrm{Rh}-\mathrm{N}$ bond lengths in $\mathbf{4}$ are comparable to those of the boron analogs that are in the range 2.083-2.114 $\AA^{23}$ 


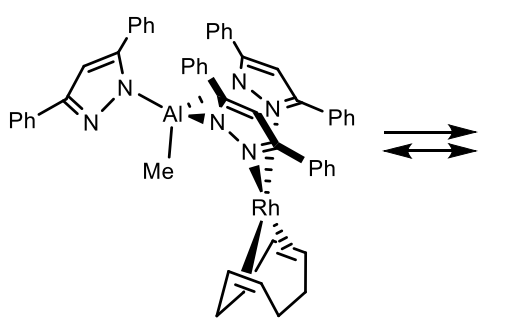

A

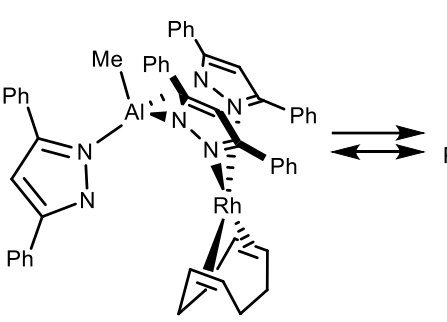

B

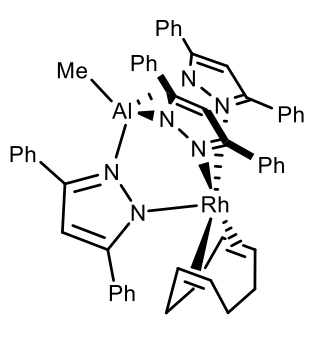

C

Scheme 2. Possible conformers for 4 in solution.
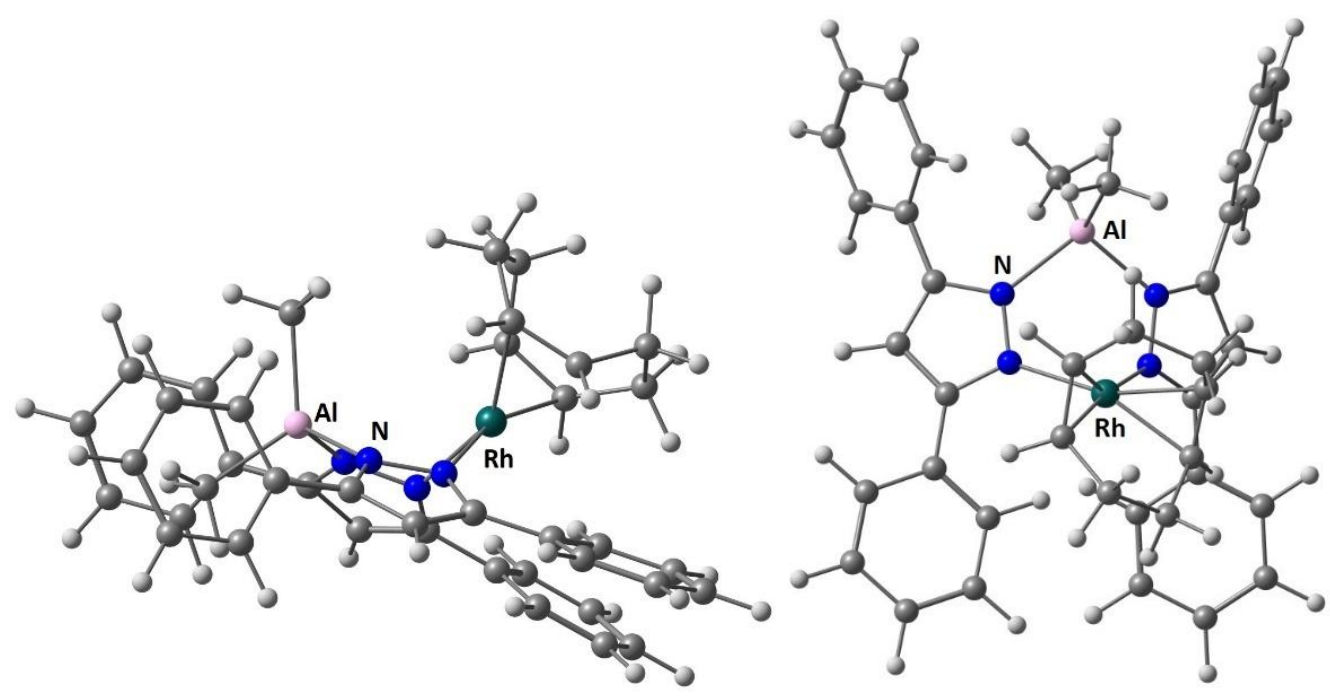

Figure 3. DFT PBE0 gas phase structure of 3. Relevant bond lengths ( $)$ and angles (deg): AlC-H 1.105, 1.105, 1.07, 1.08, 1.107, 1.107, Al-C 1.990, 1.999; Al-N 2.007, 2.008; Rh-N 2.132, 2.100; C-Al-C 121.43, C-Al-N 110.66, 109.14; N-Al-N 103.25; N-Rh-N 88.13. 


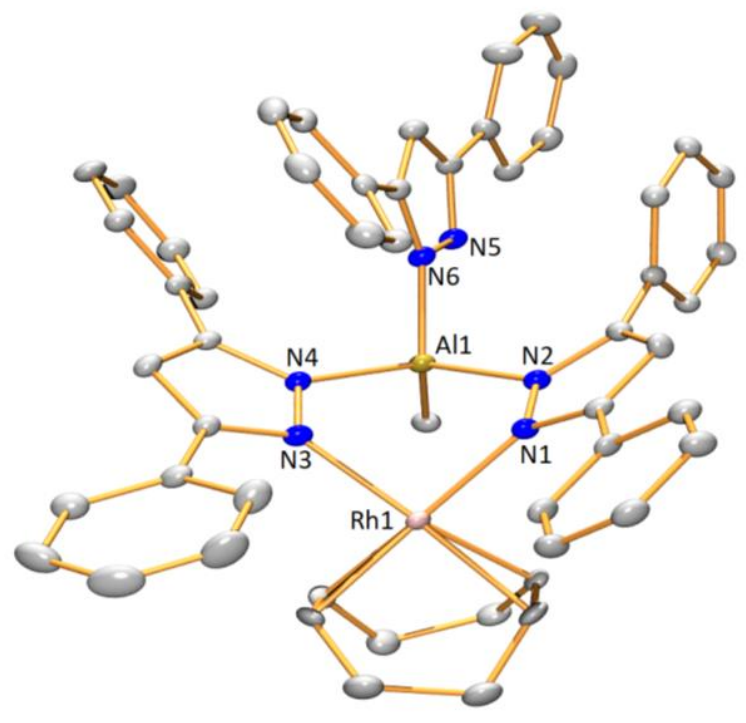

Figure 4. Perspective view of the X-ray structure of $\mathbf{4}$ showing thermal ellipsoids at the $30 \%$ probability level. Hydrogen atoms have been removed for clarity. Relevant bond lengths (A) and angles (deg): Rh(1)-N(1) 2.095(3), Rh(1)-N(3) 2.097(3), Al(1)-N(4) 1.928(3), Al(1)-N(2) 1.933(3), $\mathrm{Al}(1)-\mathrm{N}(6)$ 1.882(3), $\mathrm{Al}(1)-\mathrm{C}(46) 1.942(4) ; \mathrm{N}(1)-\mathrm{Rh}(1)-\mathrm{N}(3)$ 86.90(12), N(3)-Rh(1)C48 92.94(14), N(1)-Rh(1)-C(52) 89.85(14), N(4)-Al(1)-N(2) 105.67(13), N(6)-Al(1)-N(4) 102.69(14), N6-Al1-N2 102.45(14), N6-Al1-C46 116.85(16); N4-Al1-C46 112.81(16); N2-Al1C46 114.91(16).

\subsection{Polymerization of phenylacetylene by catalysts 3 and $\mathbf{4}$}

We sought to compare the catalytic activity of rhodium polypyrazolilaluminates $\mathbf{3}$ and $\mathbf{4}$ with their boron analogs $\left[\mathrm{Bp}^{\mathrm{R}, \mathrm{R}} \mathrm{RhCOD}\right]$ and $\left[\mathrm{Tp}^{\mathrm{R}, \mathrm{R}} \mathrm{RhCOD}\right]$. Published data for the latter borates are available for the polymerization of phenylacetylene (PA) ${ }^{23,28-29}, \mathrm{Eq} 1$, and Table 1. Consequently, we proceeded to carry out the polymerization of PA with $\mathbf{3}$ and $\mathbf{4}$ in DCM using a catalyst loading of $0.7 \%$ and in conditions given in Table 1 . The IR spectra of isolated yellow polyphenylacetylene (PPA) from $\mathbf{3}$ and $\mathbf{4}$ show cis-PPA according to two strong absorptions at 
755 and $738 \mathrm{~cm}^{-1}$ and a broad one at $885 \mathrm{~cm}^{-1}$. An overall highly stereoregular polymer with cistransoidal structure is inferred from a sharp singlet resonance at $\delta 5.84$ in the ${ }^{1} \mathrm{H}$ NMR spectrum Integration revealed a cis content higher than $90 \%^{29-31}$ (Figures S7, S8, and Eq S2). Cistransoidal PPA was also isolated from boron analogs ${ }^{23,29}$ of $\mathbf{3}$ and $\mathbf{4}$. Remarkably complexes $\mathbf{3}$ and 4 polymerize PA considerably faster $\left[15-60\right.$ min at $0{ }^{\circ} \mathrm{C}$, entries $\left.1-4\right]$ than their boron counterparts [hours between 20 to $40^{\circ} \mathrm{C}$, entries 6-14]. The isolated polymers show molecular weights, $M_{\mathrm{n}}$, ranging from $4.2 \times 10^{4}$ to $8.9 \times 10^{4}$ and $Ð$ from 2.02 to 2.69 . The enhanced catalytic activity of complexes $\mathbf{3}$ and $\mathbf{4}$ is ascribed to the unsaturated coordination $\kappa^{2}$ form. The $\kappa^{2}$ form is favored with large substituents on the pyrazolyl rings and with complexes having COD as a ligand instead of NBD. Indeed, some [TpRhNBD] complexes show modest catalytic activity and $\left[\mathrm{TpRh}(\mathrm{CO})_{2}\right]$ complexes are inactive. ${ }^{23,29}$ According to the NMR data of the polymerization reactions before quenching, there is no significant degradation of complexes $\mathbf{3}$ and $\mathbf{4}$ (Figures S2, and S4), suggesting dissociation of the diene is most likely not the event that initiates polymerization, as is the case with [TpRhCOD] borate analogs $\mathrm{s}^{23,29}$.

Catalysts 3 and 4 were isolated with a minor content of $\left[\mathrm{Rh}\left(\mathrm{Ph}_{2} \mathrm{pz}\right)(\mathrm{COD})\right]_{2}$. The latter was tested under the same reaction conditions for PA polymerization as $\mathbf{3}$ and $\mathbf{4}$ with no noticeable formation of PPA during reaction time, and after workup, only unreacted PA was isolated.

Obvious questions for complexes $\mathbf{3}$ and $\mathbf{4}$ is how the aluminate ligand system compares to the borate ligands in terms of bite angle (taken from measured N-Rh-N angles in a similar manner as P-M-P bite angles for phosphines), ${ }^{32}$ and electronic properties and if both factors influence the catalytic polymerization of PA. The lack of a crystal structure for $\mathbf{3}$ and crystallographic data of rhodium poly(pyrazolyl)borate analogs prompted us to explore gas phase DFT structures of $\mathbf{3}, \mathbf{4}$, and their boron counterparts $\left[\mathrm{Rh}(\mathrm{COD})\left\{\mathrm{B}\left(\mathrm{Ph}_{2} \mathrm{pz}\right)_{2} \mathrm{Me}_{2}\right\}\right]$, and $\left[\mathrm{Rh}(\mathrm{COD})\left\{\mathrm{B}\left(\mathrm{Ph}_{2} \mathrm{pz}\right)_{3} \mathrm{Me}\right\}\right]$ which 
are shown in the SI. The electronic situation of the rhodium center in $\mathbf{3}$ and $\mathbf{4}$ compared to analogous borates was probed indirectly by the IR CO stretching modes of optimized 3-CO, 4CO, $\left[\mathrm{Rh}(\mathrm{CO})_{2}\left\{\mathrm{~B}\left(\mathrm{Ph}_{2} \mathrm{pz}\right)_{2} \mathrm{Me}_{2}\right\}\right]$, and $\left[\mathrm{Rh}(\mathrm{CO})_{2}\left\{\mathrm{~B}\left(\mathrm{Ph}_{2} \mathrm{pz}\right)_{3} \mathrm{Me}\right\}\right]$ (Table S4). The COD derivatives show wider bite angles for $\mathbf{3}$ and $\mathbf{4},\left(88\right.$ and $89^{\circ}$, respectively. The same angle in the solid state structure of 4 is $\left.87^{\circ}\right)$, than for complexes $\left[\mathrm{Rh}(\mathrm{COD})\left\{\mathrm{B}\left(\mathrm{Ph}_{2} \mathrm{pz}\right)_{2} \mathrm{Me}_{2}\right\}\right]$ and $\left[\mathrm{Rh}(\mathrm{COD})\left\{\mathrm{B}\left(\mathrm{Ph}_{2} \mathrm{pz}\right)_{3} \mathrm{Me}\right\}\right]\left(84^{\circ}\right)$. Bite angles for these borates are within the range of those crystallographycally characterized in entries 11 to 13 of Table 1 which span from 82 to $83^{\circ} .{ }^{23}$ The symmetric and antisymmetric $\mathrm{CO}$ stretching modes of 3-CO and 4-CO are consistently 2 to 4 wavenumbers higher than for $\left[\mathrm{Rh}(\mathrm{CO})_{2}\left\{\mathrm{~B}\left(\mathrm{Ph}_{2} \mathrm{pz}\right)_{2} \mathrm{Me}_{2}\right\}\right]$, and $\left[\mathrm{Rh}(\mathrm{CO})_{2}\left\{\mathrm{~B}\left(\mathrm{Ph}_{2} \mathrm{pz}\right)_{3} \mathrm{Me}\right\}\right]$ implying rhodium been slightly less electron-rich in the rhodium-aluminate complexes. Therefore, current data available highlight that replacing $\mathrm{B}$ for $\mathrm{Al}$ in $\mathrm{Bp}$ and $\mathrm{Tp}$ complexes of $\mathrm{Rh}$ result in better performance of the catalytic active species during polymerization of PA due to wider bite angles and a more electron-deficient rhodium center.

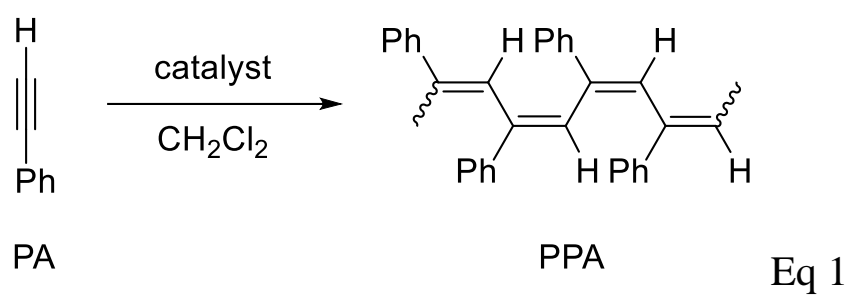

Table 1. Polymerization of PA using catalysts $\mathbf{3}, \mathbf{4}$, and $\left[\mathrm{Rh}\left(\mathrm{Ph}_{2} \mathrm{pz}\right)(\mathrm{COD})\right]_{2}{ }^{a}$

\begin{tabular}{|c|c|c|c|c|c|c|}
\hline Entry & Catalyst & $\begin{array}{c}\text { Temperature } \\
\left({ }^{\circ} \mathrm{C}\right)\end{array}$ & $\begin{array}{c}\text { Time } \\
(\min )\end{array}$ & $\begin{array}{c}\text { Conversion } \\
(\%)\end{array}$ & $\begin{array}{c}M_{\mathrm{n}}{ }^{c} \\
10^{-4}\end{array}$ & $M_{\mathrm{w}} / M_{\mathrm{n}}$ \\
\hline 1 & $\mathbf{3}$ & 20 & 60 & 85 & 8.9 & 2.12 \\
\hline 2 & $\mathbf{3}$ & 0 & 60 & 99 & 7.6 & 2.20 \\
\hline 3 & $\mathbf{4}$ & 20 & 15 & 98 & 4.2 & 2.02 \\
\hline 4 & $\mathbf{4}$ & 0 & 15 & 97 & 5.1 & 2.69 \\
\hline 5 & {$\left[\mathrm{Rh}\left(\mathrm{Ph}_{2} \mathrm{pz}\right)(\mathrm{COD})\right]_{2}$} & 20 & 60 & 0 & - & - \\
\hline $6^{c}$ & {$\left[\mathrm{Bp}^{\mathrm{Me}} \mathrm{Rh}(\mathrm{COD})\right]$} & 40 & 1440 & 84 & 3.2 & 2.43 \\
\hline
\end{tabular}




\begin{tabular}{|c|c|c|c|c|c|c|}
\hline $7^{d}$ & {$\left[\mathrm{Bp}^{(\mathrm{CF} 3) 2} \mathrm{Rh}(\mathrm{COD})\right]$} & 40 & 1440 & 92 & 2.1 & 2.34 \\
\hline $8^{d}$ & {$\left[\mathrm{Tp}^{\mathrm{Ph} 2} \mathrm{Rh}(\mathrm{COD})\right]$} & 40 & 1440 & 98 & 1.5 & 2.48 \\
\hline $9^{d}$ & {$\left[\mathrm{Tp}^{\mathrm{Me} 2} \mathrm{Rh}(\mathrm{COD})\right]$} & 40 & 1440 & 98 & 1.5 & 2.48 \\
\hline $10^{d}$ & {$\left[\mathrm{Tp}^{\mathrm{iPr} 2} \mathrm{Rh}(\mathrm{COD})\right]$} & 40 & 180 & 99 & 2.7 & 2.32 \\
\hline $11^{e}$ & {$\left[\mathrm{Tp}{ }^{\mathrm{Ph}, \mathrm{Me}} \mathrm{Rh}(\mathrm{COD})\right]$} & 20 & 1440 & 96 & 2.0 & 2.38 \\
\hline $12^{e}$ & $\begin{array}{c}{\left[\mathrm{HB}(3-\mathrm{Ph}, 5-\mathrm{Mepz})_{2}(3-\mathrm{Me}, 5-\right.} \\
\mathrm{Phpz}) \mathrm{Rh}(\mathrm{COD})]\end{array}$ & 20 & 1440 & 98 & 0.9 & 2.03 \\
\hline $13^{e}$ & $\begin{array}{c}{\left[\mathrm{HB}(3-\mathrm{Ph}, 5-\mathrm{Mepz})_{2}(3,5-\right.} \\
\text { diEtpz)Rh(COD) }\end{array}$ & 20 & 1440 & 100 & 3.4 & 2.48 \\
\hline $14^{d}$ & {$[\mathrm{TpRh}(\mathrm{COD})]$} & 40 & 1440 & 2 & - & - \\
\hline
\end{tabular}

${ }^{a}$ Catalyst loading $0.7 \% .{ }^{b} \%$ of PPA determined by ${ }^{1} \mathrm{H}$ NMR in dichloromethane- $d_{2} .{ }^{c}$ Determined by GPC based on polystyrene standards. References $29^{d}$ and $23^{e}$, respectively.

\subsection{Complexation of other bis and tris (pyrazolyl)aluminates to $[\mathrm{Rh}(\mathrm{COD}) \mathrm{Cl}]_{2}$ and} decomposition reaction energetics of bis and tris(pyrazolyl)aluminate rhodium complexes by DFT computations

Having at hand phenyl substituted complexes $\mathbf{3}$ and $\mathbf{4}$, we sought to synthesize other rhodiumaluminate derivatives with $\mathrm{R}=\mathrm{CF}_{3}$ and ${ }^{\mathrm{t}} \mathrm{Bu}$ substituents on the pyrazol ring namely $\left[\mathrm{Rh}(\mathrm{COD})\left\{\mathrm{Al}\left(\left(\mathrm{CF}_{3}\right)_{2} \mathrm{pz}\right)_{\mathrm{n}} \mathrm{Me}_{4-\mathrm{n}}\right\}\right]$ and $\left[\mathrm{Rh}(\mathrm{COD})\left\{\mathrm{Al}\left({ }^{\mathrm{t}} \mathrm{Bu}_{2} \mathrm{pz}\right)_{\mathrm{n}} \mathrm{Me}_{4-\mathrm{n}}\right\}\right]$ with $\mathrm{n}=2$, 3. Sodium bis(3,5-tert-butylpyrazolyl)aluminate, $\left[\left\{\mathrm{Na}(\mathrm{THF})_{2}\right\}\left\{\mathrm{Al}\left({ }^{\mathrm{t}} \mathrm{Bu}_{2} \mathrm{pz}\right)_{2} \mathrm{Me}_{2}\right\}\right]$, was previously reported by us $^{18}$ and the synthesis of sodium bis(3,5-trifluoromethylpyrazolyl)aluminate, $\left[\left\{\mathrm{Na}(\mathrm{THF})_{2}\right\}\left\{\mathrm{Al}\left(\left(\mathrm{CF}_{3}\right)_{2} \mathrm{pz}\right)_{2} \mathrm{Me}_{2}\right\}\right]$, is given in the SI. Whatever the nature of $\mathrm{R}$, reaction of these sodium aluminates with $[\mathrm{Rh}(\mathrm{COD}) \mathrm{Cl}]_{2}$ at ambient temperature in toluene- $d_{8}$ gave decomposition products $\left[\mathrm{Rh}\left(\mathrm{R}_{2} \mathrm{pz}\right)(\mathrm{COD})\right]_{2}$ and $\left[\mathrm{R}_{2} \mathrm{pzAlMe}\right]_{2}$ together with unreacted $\left[\left\{\mathrm{Na}(\mathrm{THF})_{2}\right\}\left\{\mathrm{Al}\left(\mathrm{R}_{2} \mathrm{pz}\right)_{2} \mathrm{Me}_{2}\right\}\right]$. Carrying out these reactions at $100{ }^{\circ} \mathrm{C}$ for $\mathrm{R}={ }^{\mathrm{t}} \mathrm{Bu}$ afforded $\left[\mathrm{Rh}\left({ }^{\mathrm{t}} \mathrm{Bu}_{2} \mathrm{pz}\right)(\mathrm{COD})\right]_{2}$ and $\left[{ }^{\mathrm{t}} \mathrm{Bu}_{2} \mathrm{pz} \mathrm{AlMe}_{2}\right]_{2}$ in a 1:1 ratio $\left({ }^{1} \mathrm{HNMR}\right.$ Figure $\left.\mathrm{S} 28\right)$, whereas for $\mathrm{R}=$ $\mathrm{CF}_{3}$ only $\left[\mathrm{Rh}\left\{\left(\mathrm{CF}_{3}\right)_{2} \mathrm{pz}\right\}(\mathrm{COD})\right]_{2}$ was detected in solution $\left({ }^{1} \mathrm{H},{ }^{13} \mathrm{CNMR}\right.$ Figure S26).

Strikingly, the ${ }^{1} \mathrm{HNMR}$ spectrum for the $\mathrm{CF}_{3}$ derivative also showed the presence of methane $(\delta$ 0.18) implying the formation of a sodium alkyl aluminate or an alkyl aluminum compound that 
eventually decomposed. Before attempting the synthesis of rhodium tris(pyrazolyl)aluminates, we performed DFT calculations at the $\omega \mathrm{B} 97 \mathrm{M}-\mathrm{V} / \mathrm{def} 2-\mathrm{TZVPP}$ level of theory to estimate the differences in energies of the coveted rhodium tris(pyrazolyl)aluminates and their possible decomposition products in bimolecular metathesis reactions as shown in Eq 2 and Table S3. Reactions I and II ( $\mathrm{R}=\mathrm{Ph}, \mathrm{CF}_{3}$, respectively) are endothermic $\left(\Delta \mathrm{E}=7.2,20.8 \mathrm{kcalmol}^{-1}\right.$, respectively), while reaction III $\left(\mathrm{R}={ }^{\mathrm{t}} \mathrm{Bu}\right)$ is almost thermoneutral. Therefore, the $\mathrm{CF}_{3}$ derivative $\left.\left[\mathrm{Rh}(\mathrm{COD})\left\{\mathrm{Al}\left(\mathrm{CF}_{3}\right)_{2} \mathrm{pz}\right)_{3} \mathrm{Me}\right\}\right]$ would be the species most likely to be isolated on thermodynamic grounds, with the next most likely being 4 . It can be seen from the crystal structure of 4 (Figure 4) and its optimized geometry in the gas phase shown in the SI that $\pi-\pi$ contacts (X-ray: 3.48 and $3.79 \AA$; DFT: 3.88 and $3.92 \AA$ ) of the loose pyrazolate flanked with phenyl rings from the $\kappa^{2}$-pyrazolates play an important role in the overall stabilization of the complex by restricting the $\mathrm{C}-\mathrm{C}$ rotation of phenyl rings and consequently diminishing Van der Waals repulsions. From the $\Delta \mathrm{E}$ of reaction II and the optimized geometry of $\left.\left[\mathrm{Rh}(\mathrm{COD})\left\{\mathrm{Al}\left(\mathrm{CF}_{3}\right)_{2} \mathrm{pz}\right)_{2} \mathrm{Me}_{2}\right\}\right]$ shown in the SI, it can be inferred that Van der Waals repulsions between $\mathrm{CF}_{3}$ substituents due to $\mathrm{C}-\mathrm{C}$ bond rotation may favor the decomposition reaction II, precluding the possibility to isolate $\left[\mathrm{Rh}(\mathrm{COD})\left\{\mathrm{Al}\left(\mathrm{CF}_{3}\right)_{2} \mathrm{pz}_{2} \mathrm{Me}_{2}\right\}\right]$ and $\left.\left[\mathrm{Rh}(\mathrm{COD})\left\{\mathrm{Al}\left(\mathrm{CF}_{3}\right)_{2} \mathrm{pz}\right)_{3} \mathrm{Me}\right\}\right]$. Most probably $\left.\left[\mathrm{Rh}(\mathrm{COD})\left\{\mathrm{Al}\left(\mathrm{CF}_{3}\right)_{2} \mathrm{pz}\right)_{2} \mathrm{Me}_{2}\right\}\right]$ should present even smaller Van der Waals repulsions than $\left.\left[\mathrm{Rh}(\mathrm{COD})\left\{\mathrm{Al}\left(\mathrm{CF}_{3}\right)_{2} \mathrm{pz}\right)_{3} \mathrm{Me}\right\}\right]$. The fact that rhodium bis(pyrazolyl)aluminates $\left.\left[\mathrm{Rh}(\mathrm{COD})\left\{\mathrm{AlR}_{2} \mathrm{pz}\right)_{2} \mathrm{Me}_{2}\right\}\right]$ with $\mathrm{R}={ }^{\mathrm{t}} \mathrm{Bu}$ and $\mathrm{CF}_{3}$ cannot be isolated under conditions reported herein did not encourage us to attempt the synthesis of rhodium tris(pyrazolyl)aluminates. In the series of rhodium aluminates discussed so far, the ${ }^{t} \mathrm{Bu}$ derivatives $\left.\left[\mathrm{Rh}(\mathrm{COD})\left\{\mathrm{Al}^{\mathrm{t}} \mathrm{Bu}_{2} \mathrm{pz}\right)_{\mathrm{n}} \mathrm{Me}_{4-\mathrm{n}}\right\}\right]$ are those with the most important Van der Waals repulsions, and accordingly, the decomposition pathway dominates the reaction course. 


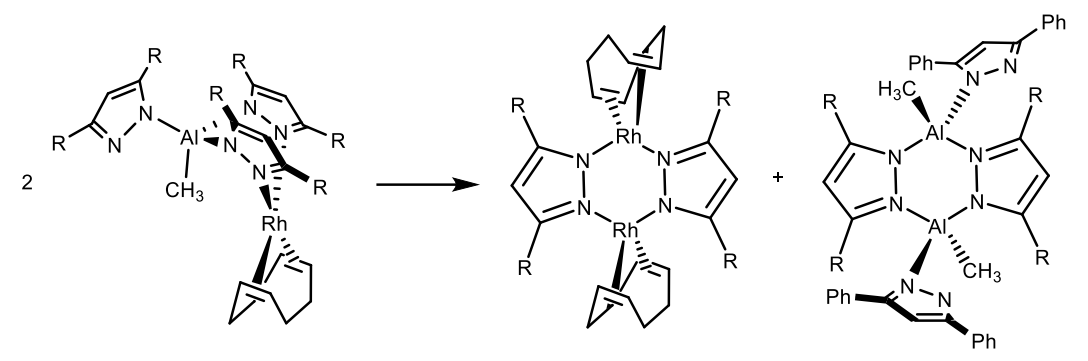

I: $\mathrm{R}=\mathrm{Ph}(\mathbf{4}) ; \mathrm{II}: \mathrm{R}=\mathrm{CF}_{3} ;$ III: $\mathrm{R}={ }^{\mathrm{t}} \mathrm{Bu}$

$\operatorname{Eq} 2$

\section{Conclusion}

Complexes $\mathbf{3}$ and $\mathbf{4}$ are the first examples of the successful transfer of a poly(pyrazolyl)aluminate to a transition metal center. The isolation of bimetallic poly(pyrazolyl)aluminate-TM complexes relies firstly on the nature of the substituents on the pyrazolate ring that minimizes electronic repulsions and therefore suppresses bimolecular metathesis. Secondly, having alkyls instead of hydrides substituents on the aluminate metalloligand suppresses undesirable substituent transfer to the TM center. Regarding the better performance of the poly(pyrazolylaluminate) ligand system in the catalytic polylmerization of PA by rhodium complexes compared to the poly(pyrazolyl)borates, it may be attributed to the wider bite angles and more electron-deficient rhodium center of the aluminate complexes. Ongoing research aims to expand the transfer of other poly(pyrazolyl)aluminates to transition metal centers for their use in homogenous catalysis.

\section{Associated Content}

\section{Supporting Information}


The Supporting Information is available free of charge at https://pubs.acs.org/. It contains experimental details and, spectroscopic, polymerization, ESI-MS, SCXRD and computational data.

\section{Accession codes}

CCDC 2081992-2081994 contains the supplementary crystallographic data for this paper. These data can be obtained free of charge via www.ccdc.cam.ac.uk/data_request/cif, or by emailing data_request@ccdc.cam.ac.uk, or by contacting The Cambridge Crystallographic Data Centre, 12 Union Road, Cambridge CB2 1EZ, UK; fax: +44 1223336033.

\section{Acknowledgments}

The authors thank MSU, CNRS-LCC and UPS Toulouse for generous support of this work, and the Mississippi Center for Supercomputing Research (MCSR) for computational resources. OJdeJG acknowledges a Ph.D. grant from CONACyT-Mexico. MAMH acknowledges sabbatical support from CONACyT-Mexico and the UPS Toulouse.

\section{References}

(1) Trofimenko, S., Scorpionates - The Coordination Chemistry of Polypyrazolylborate Ligands. Imperial College Press: London, 1999.

(2) Trofimenko, S., Recent advances in poly(pyrazolyl)borate (scorpionate) chemistry. Chem. Rev. 1993, 93, 943-980.

(3) Pettinari, C., Scorpionates II: Chelating Borate Ligands. 2008.

(4) Trofimenko, S., Scorpionates: genesis, milestones, prognosis. Polyhedron 2004, 23, 197-203.

(5) Muñoz-Hernández, M. A.; Montiel-Palma, V., Polypyrazolates of the heavier group 13 and 14 elements: A review. Inorg. Chim. Acta 2009, 362, 4328-4339.

(6) Sambade, D.; Parkin, G., Synthesis and structural characterization of tris(pyrazolyl)hydroaluminate and tris(pyrazolyl)hydrogallate lithium compounds. Polyhedron 2017, 125, 219-229.

(7) Breakell, K. R.; Patmore, D. J.; Storr, A., Synthesis of pyrazolyl-borate, -aluminate, -gallate, and indate ligands, and their chelating properties towards cobalt(II), nickel(II), copper(II), and zinc(II). $J$. Chem. Soc., Dalton Trans. 1975, 749-754.

(8) Cortes-Llamas, S.; Velázquez-Carmona, M. A.; Muñoz-Hernández, M. A., Isolation and authentication of a sodium bispyrazolylaluminate. Inorg. Chem. Commun. 2005, 8, 155-158. 
(9) Snyder, C. J.; Heeg, M. J.; Winter, C. H., Poly(pyrazolyl)aluminate Complexes Containing Aluminum-Hydrogen Bonds. Inorg. Chem. 2011, 50, 9210-9212.

(10) Plajer, A. J.; Kopf, S.; Colebatch, A. L.; Bond, A. D.; Wright, D. S.; García-Rodríguez, R., Deprotonation, insertion and isomerisation in the post-functionalisation of tris-pyridyl aluminates. Dalton Trans. 2019, 48, 5692-5697.

(11) García-Romero, Á.; Plajer, A. J.; Álvarez-Miguel, L.; Bond, A. D.; Wright, D. S.; GarcíaRodríguez, R., Postfunctionalization of Tris(pyridyl) Aluminate Ligands: Chirality, Coordination, and Supramolecular Chemistry. Chem. Eur. J. 2018, 24, 17019-17026.

(12) García-Rodríguez, R.; Simmonds, H. R.; Wright, D. S., Formation of a Heterometallic AlIII/SmIII Complex Involving a Novel [EtAl(2-py)2O]2- Ligand (2-py = 2-Pyridyl). Organometallics 2014, 33, 7113-7117.

(13) Bullock, T. H.; Chan, W. T. K.; Eisler, D. J.; Streib, M.; Wright, D. S., Metal and ligand substitution of the aluminium tris-pyridyl ligands [ $\mathrm{RAl}(2-$ py[prime or minute])3]- $(\mathrm{R}=\mathrm{Et}, \mathrm{nBu}, \mathrm{sBu}, \mathrm{tBu}$; 2-py[prime or minute] = 2-pyridyl, 3-methyl-2-pyridyl, 5-methyl-2-pyridyl, 6-methyl-2-pyridyl). Dalton Trans. 2009, 1046-1054.

(14) Garcia, F.; Hopkins, A. D.; Kowenicki, R. A.; McPartlin, M.; Silvia, J. S.; Rawson, J. M.; Rogers, M. C.; Wright, D. S., Pyridyl 'ring-flipping' in the dimers [Me2E(2-py)]2 (E = B, Al, Ga; 2-py = 2pyridyl). Chem. Commun. 2007, 586-588.

(15) García, F.; Hopkins, A. D.; Kowenicki, R. A.; McPartlin, M.; Rogers, M. C.; Silvia, J. S.; Wright, D. S., Syntheses and Structure of Heterometallic Complexes Containing Tripodal Group 13 Ligands [RE(2py)3]- (E = Al, In). Organometallics 2006, 25, 2561-2568.

(16) Alvarez, C. S.; Garcia, F.; Humphrey, S. M.; Hopkins, A. D.; Kowenicki, R. A.; McPartlin, M.; Layfield, R. A.; Raja, R.; Rogers, M. C.; Woods, A. D.; Wright, D. S., Highly selective epoxidation of styrene using a transition metal-aluminium(III) complex containing the [MeAl(2-py)3]- anion (2-py $=2$ pyridyl). Chem. Commun. 2005, 198-200.

(17) García, F.; Hopkins, A. D.; Kowenicki, R. A.; McPartlin, M.; Rogers, M. C.; Wright, D. S., Synthesis of the [MeAl(2-py)3]- Anion and Its Application as a Stable and Mild Pyridyl-Transfer Reagent (2-py = 2-Pyridyl). Organometallics 2004, 23, 3884-3890.

(18) Cortes-Llamas, S. A.; Muñoz-Hernández, M. Á., Sodium polypyrazolylaluminates: Synthesis, characterization, and isolation of a reaction intermediate of a trispyrazolylaluminate. Organometallics 2007, 26, 6844-6851.

(19) Yu, Z. K.; Wittbrodt, J. M.; Heeg, M. J.; Schlegel, H. B.; Winter, C. H., Unusually stable pyrazolate-bridged dialuminum complexes containing bridging methyl groups. J. Am. Chem. Soc. 2000, $122,9338-9339$.

(20) Lewiński, J.; Zachara, J.; Goś, P.; Grabska, E.; Kopeć, T.; Madura, I.; Marciniak, W.; Prowotorow, I., Reactivity of Various Four-Coordinate Aluminum Alkyls towards Dioxygen: Evidence for Spatial Requirements in the Insertion of an Oxygen Molecule into the $\mathrm{Al}-\mathrm{C}$ Bond. Chem. Eur. J. 2000, 6, 32153227.

(21) Kosuru, S. R.; Sun, T.-H.; Wang, L.-F.; Vandavasi, J. K.; Lu, W.-Y.; Lai, Y.-C.; Hsu, S. C. N.; Chiang, M. Y.; Chen, H.-Y., Enhanced Catalytic Activity of Aluminum Complexes for the Ring-Opening Polymerization of $\varepsilon$-Caprolactone. Inorg. Chem. 2017, 56, 7998-8006.

(22) Andrikopoulos, P. C.; Armstrong, D. R.; Barley, H. R. L.; Clegg, W.; Dale, S. H.; Hevia, E.; Honeyman, G. W.; Kennedy, A. R.; Mulvey, R. E., Sodium dialkyl-amidozincates: Alkyl or amido bases? An experimental and theoretical case study. J. Am. Chem. Soc. 2005, 127, 6184-6185.

(23) Ruman, T.; Ciunik, Z.; Trzeciak, A. M.; Wołowiec, S.; Ziółkowski, J. J., Complexes of Heteroscorpionate Trispyrazolylborate Ligands. Part 10. Structures and Fluxional Behavior of Rhodium(I) Complexes with Heteroscorpionate Trispyrazolylborate Ligands, Tp" 'Rh(LL) (LL = (CO)2 or COD). Organometallics 2003, 22, 1072-1080.

(24) Bucher, U. E.; Currao, A.; Nesper, R.; Rueegger, H.; Venanzi, L. M.; Younger, E., .kappa.2.kappa.3 Isomerism in Rhodium(I) Tris(pyrazolyl)borate Complexes of the Type Tp3R,4R,5RRh(LL) (LL 
$=2 \mathrm{CO}, \mathrm{COD}$, and NBD) and Their Dynamic Behavior in Solution. X-ray Crystal Structure of $\mathrm{TpMeRh}(\mathrm{NBD})$. Inorg. Chem. 1995, 34, 66-74.

(25) Sanz, D.; Santa María, M. D.; Claramunt, R. M.; Cano, M.; Heras, J. V.; Campo, J. A.; Ruíz, F. A.; Pinilla, E.; Monge, A., Regular paper. J. Organomet. Chem. 1996, 526, 341-350.

(26) Akita, M.; Ohta, K.; Takahashi, Y.; Hikichi, S.; Moro-oka, Y., Synthesis and Structure Determination of Rh-diene Complexes with the Hydridotris(3,5-diisopropylpyrazolyl)borate Ligand, TpiPrRh(diene) $($ diene $=$ cod, nbd): Dependence of the $v(\mathrm{~B}-\mathrm{H})$ Values on the Hapticity of the TpiPr

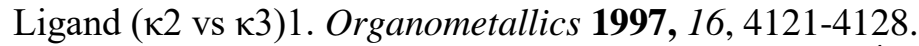

(27) Conejero, S.; Esqueda, A. C.; Valpuesta, J. E. V.; Álvarez, E.; Maya, C.; Carmona, E., Different coordination modes of an aryl-substituted hydrotris(pyrazolyl)borate ligand in rhodium and iridium complexes. Inorg. Chim. Acta 2011, 369, 165-172.

(28) Casado, M. A.; Fazal, A.; Oro, L. A., Rhodium-Catalyzed Polymerization of Phenylacetylene and its Derivatives. Arab. J. Sci. Eng. 2013, 38, 1631-1646.

(29) Katayama, H.; Yamamura, K.; Miyaki, Y.; Ozawa, F., Stereoregular Polymerization of Phenylacetylenes Catalyzed by [Hydridotris(pyrazolyl)borato]rhodium(I) Complexes. Organometallics 1997, 16, 4497-4500.

(30) Furlani, A.; Licoccia, S.; Russo, M. V.; Camus, A.; Marsich, N., Rhodium and platinum complexes as catalysts for the polymerization of phenylacetylene. J. Polym. Sci., Part A: Polym. Chem. 1986, 24, 991-1005.

(31) Simionescu, C. I.; Percec, V.; Dumitrescu, S., Polymerization of acetylenic derivatives. XXX. Isomers of polyphenylacetylene. J. Polym. Sci.: Polym. Chem. Ed. 1977, 15, 2497-2509.

(32) Dierkes, P.; Leeuwen, P. W. N. M. v., The bite angle makes the difference: a practical ligand parameter for diphosphine ligands. J. Chem. Soc., Dalton Trans. 1999, 1519-1529. 